Ks. Norbert WIDOK*

\title{
KLEMENS RZYMSKI O SUKCESJI APOSTOLSKIEJ
}

Klemens Rzymski $(† 101)^{1}$, którego niedawno obchodzona 1910. rocznica śmierci była zauważona w świecie nauki ${ }^{2}$ jest autorem Listu do Koryntian, będącego ważnym świadectwem najwcześniejszego okresu rozwoju chrześcijaństwa ${ }^{3}$. Zajmuje się w nim przede wszystkim problemami o charakterze dyscyplinarnym, które opatruje interpretacjami teologicznymi wynikającymi z ówczesnej refleksji nad przekazami biblijnymi, a także kwestiami związanymi z wczesną fazą rozwoju Kościoła katolickiego ${ }^{4}$. Dominacja w tym liście spraw dyscyplinujących koryncką wspólnotę wynika z zaistniałych w niej prób niedostosowania się niektórych jej członków do przyjętej już lub też tworzącej się zasady egzystowania tej wspólnoty w ramach tamtejszego Kościoła. Wiadomo, że w Koryncie kościelną wspólnotę założył św. Paweł, który już wcześniej przesłał do niej dwa listy zawierające przesłanie interpretujące bieżące problemy, również dotyczące kwestii dyscyplinarnych i teologicznych.

1. Kwestia prymatu. List Klemensa był przedmiotem wielu opracowań 2. poł. XX w. m.in. podejmujących kwestię prymatu w Kościele katolickim5 . Najogólniej mówiąc, ich autorzy podkreślali przywilej posiadania prymatu przez Klemensa Rzymskiego, i to w ujęciu współczesnego pojmowania.

\footnotetext{
* Ks. dr hab. Norbert Widok, prof. UO - profesor nadzwyczajny w Katedrze Historii Kościoła i Patrologii na Wydziale Teologicznym Uniwersytetu Opolskiego; e-mail: nwidok@uni.opole.pl.

${ }^{1} \mathrm{Na}$ jego temat por. J. Hofmann, Unser heiliger Vater Klemens. Ein römischer Bischof im Kalender der griechischen Kirche, Trier 1992, 6-118.

${ }^{2}$ Zob. m.in. konferencję naukową w Chersonezie, miejscu męczeńskiej śmierci Klemensa, zorganizowana przez The National Preserve of Tauric Chersonesos, the Crimean branch of the Institute of Archeology of the National Academy of Science of Ukraine, and the Simferopol and Crimean Diocese: VI International Scientific Conference on Church Archeology: „Chersonesos - the City of Saint Clement", Ukraine, Crimea, Sevastopol, National Preserve of Tauric Chersonesos, September 12-18, 2011.

${ }^{3}$ Przyjmuje się, że został zredagowany ok. 95 r. Por. Th.J. Herron, Clement and the Early Church of Rome: On the Dating of Clement's First Epistle to the Corinthians, Steubenville 2008, 7.

${ }^{4}$ Por. K. Beyschlag, Clemens Romanus und der Frühkatholizismus, Tübingen 1966.

${ }^{5}$ Zagadnienie prymatu podejmowane przez poszczególnych autorów ujętych chronologicznie opracował W. Turek (,Prima Clementis”: zagadnienie prymatu biskupa Rzymu w ujęciu współczesnych opracowań patrystycznych, VoxP 24 (2004) t. 46-47, 33-49). Wśród nich zostali wymienieni: J. Quasten, A. Jaubert, R. Minnerath, A. Lindemann, E. Peretto, J. Fuellenbach i G. Falbo.
} 
W tym czasie obok opinii wyrażających poparcie dla istnienia prymatu pojawiają się głosy negujące tę tezę. Przykładem tego jest Nikolai Afanassieff, który - analizując pozdrowienie umieszczone na początku listu, a także inne zawarte w nim sformułowania - dowodzi, że nie wynika z niego jakoby Kościół rzymski posiadał wyższą pozycję aniżeli Kościół w Koryncie ${ }^{6}$. Najnowsze badania tego zagadnienia obalają tezę o istnieniu prymatu w czasie redagowania listu do gminy w Koryncie i formułują inną o nim definicję w odniesieniu do pierwszych wieków chrześcijaństwa. Uważa się, że pozycja biskupa Rzymu przechodziła swego rodzaju ewolucję, począwszy „od proszenia o informację, przez domaganie się kosultacji, do wymagania posłuszeństwa"7. Dojrzała postać prymatu była obecna dopiero za pontyfikatu Leona Wielkiego (440-461), choć przed nim sukcesywnie rozwijała się jego świadomość, zwłaszcza w znaczeniu prymatu władzy, u Aniceta (155-166), nieco głębiej u Wiktora I (189199), a najbardziej u Damazego I (366-384). Po nim kolejni papieże posiadają już zatem w pełni ukształtowaną naukę o prymacie ${ }^{8}$. Tę tezę potwierdza także M. Simonetti, który we wprowadzeniu do najnowszego wydania krytycznego listu Klemensa wyraźnie zaznacza, że nie istniała w Rzymie pod koniec I w. jakakolwiek forma prymatu?.

Mając na uwadze powyższe założenie, poszczególne kwestie zamieszczone w liście Klemensa należy zatem rozpatrywać w innej perspektywie historycznej i jednocześnie metodologicznej. W związku z tak pojmowaną pozycją biskupa Rzymu pojawia się pytanie o powód interwencji w sprawach lokalnego Kościoła w odległym od Rzymu Koryncie. Wczytując się w niektóre szczegóły tekstu tego listu - jak to pokazał Andrew Gregory - można się dowiedzieć, że list do Koryntu został napisany z własnej inicjatywy, bez otrzymania oficjalnej prośby o pomoc, ale w oparciu o wiadomości, które dotarły do Rzymu ${ }^{10}$. W Koryncie bowiem rowinęła się forma tzw. kościołów domowych, wprowadzona jeszcze przez św. Pawła za czasów jego pobytu w tym mieście,

${ }^{6}$ Por. N. Afanassieff, Das Hirtenamt der Kirche: in der Liebe der Gemeinde vorstehen, w: Der Primat des Petrus in der orthodoxen Kirche, hrsg. B. Bobrinskow - O. Clément - B. Fize - J. Meyendorf, Zürich 1961, 45: „Wenn Rom der Meinung gewesen wäre, die größere Macht zu besitzen als Korinth, so wären Ton und Sprache des Briefes bestimmt ganz anders ausgefallen".

${ }^{7}$ H. Pietras, Początki teologii Kościoła, Kraków 2007², 117.

${ }^{8}$ Por. Cz. Bartnik, Nauka Leona Wielkiego o prymacie biskupa Rzymu, VoxP 24 (2004) t. 46-47, 312. Zob. K. Schatz, Prymat papieski od początków do współczesności, thum. E. Marszal - J. Zakrzewski, Kraków 2004, 23-67.

${ }^{9}$ Por. E. Prinzivalli - M. Simonetti, Introduzione. La lettera di Clemente ai Corinzi, w: Seguendo Gesù. Testi cristiani delle origini, ed. E. Prinzivalli - M. Simonetti, vol. 1, Borgaro Torinese 2010, 85: „Tutto ciò trova conferma nella struttura e nella forma letteraria di IClem: l’intento di persuadere informa ogni passaggio, imponendo la conclusione che Roma non ha nessuna autorità particolare, nessun primato riconosciuto in quel momento storico, non dà affatto per scontato che il suo intervento sarà accolto, e non ha sanzioni da minacciare, tranne il giudizio di Dio".

${ }^{10}$ Por. A. Gregory, ,, 1 Clement”: An Introduction, w: The Writings of the Apostolic Fathers, ed. P. Foster, London 2007, 25. 
na czele których stali poszczególni prezbiterzy. Po jego śmierci następował dalszy rozwój struktury kościelnej prowadzący jednak do wewnętrznych podziałów o charakterze sekciarskim ${ }^{11}$. Ten etap rozwoju struktury eklezjalnej w Koryncie okazał się na tyle wówczas znany, że wiadomości o niej dotarły aż do Rzymu.

Ówczesną sytuację w Koryncie umiejętnie wykorzystał Klemens ${ }^{12}$. Będąc bowiem uczniem św. Pawła (w Rzymie), doskonale był zorientowany co do jego działalności ewangelizacyjno-misyjnej w tym mieście i zaistniałych wówczas problemów w tamtejszej wspólnocie ${ }^{13}$. Klemensowi zatem łatwiej było zrozumieć doniesienia, jakie otrzymał w sprawie kolejnych nieporozumień, które pojawiły się w korynckim Kościele. Jako biskup Rzymu, a więc wspólnoty, którą opiekował się najpierw św. Piotr, poczuwał się do odpowiedzialności za tę tak bliską jego sercu cząstkę Kościoła. Powodem napisania listu - jak sugeruje Joachim Gnilka - mogła też być obustronna troska i odpowiedzialność, potrzeba wzajemnego napominania się, a także duchowe wspieranie się $\mathrm{w}$ trudnej sytuacji prawnej chrześcijan ${ }^{14}$. Warto zatem prześledzić jedną z kwestii dyscyplinarnych, porządkującą wiarygodność przekazywanej misji apostolskiej, a nazwanej później sukcesją apostolską.

2. Zarzewie kwestii dyscyplinarnej. Wspomniany powód napisania Listu do Koryntian został przez Klemensa wyraźnie podany. Z treści listu bowiem wynika, że do Rzymu dotarła wieść o zaistniałych wydarzeniach w Koryncie, które u rzymskiego biskupa wyzwoliły pragnienie wysłania do tamtejszych współwyznawców odpowiedniego pouczenia, a nawet napomnienia. Kieruje do nich takie słowa:

„[...] nie mogliśmy zająć się wcześniej sprawami, o jakie się spieracie, a zwłaszcza owym buntem, wstrętnym i bezbożnym, który winien być czymś całkiem obcym dla wybranych Boga, a który wznieciło wśród was kilku samowolnych zuchwalców"15.

${ }^{11}$ Szerokie podłoże przeróżnych okoliczności historycznych, korzystając z badań wielu autorów, przedstawił H.O. Maier, The Social Setting of the Ministry as Reflected in the Writings of Hermas, Clement and Ignatius, Waterloo 2002², 87-108.

${ }^{12}$ Znana jest opinia oparta o przekaz Euzebiusza, że biskup Koryntu, Dionizy, jako pierwszy przypisał list Klemensowi; zob. J. Gnilka, Piotr i Rzym, tłum W. Szymona, Kraków 2002, 246.

${ }^{13}$ To zagadnienie opisują m.in.: L. Sanders, L’hellénisme de saint Clément de Rome et le paulinisme, Louvain 1943; N. Spaccapelo, „Discepolo di Pietro e Paulo”. Sull'identità di Clemente Romano, w: Pietro e Paulo. Il loro rapporto con Roma nelle testimonianze antiche, SEA 74, Roma 2001, 169-179.

${ }^{14}$ Por. Gnilka, Piotr i Rzym, s. 249.

${ }^{15}$ Clemens Romanus, Epistula ad Corinthios I 1, ed. A. Jaubert, SCh 167, Paris 1971, 98: „[...]

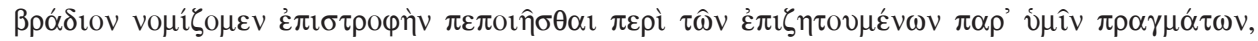

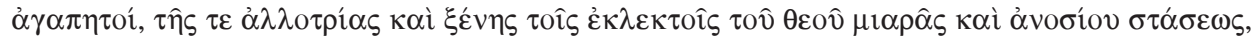

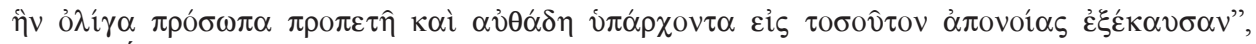
thum. A. Świderkówna, BOK 10, Kraków 1998, 51. 
Przytoczony tekst zawiera kilka informacji przedstawiających najistotniejsze aspekty owej skomplikowanej sytuacji. Klemens, w odpowiedzi na otrzymane relacje dotyczące kondycji korynckiej wspólnoty, nazywa „buntem”

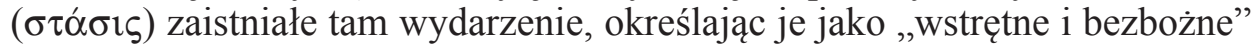

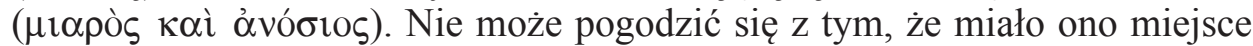

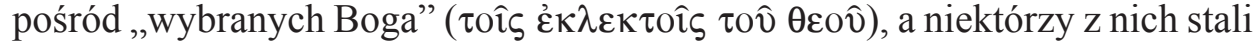

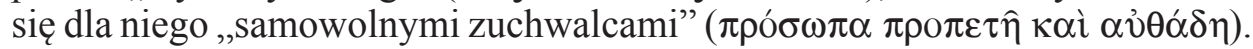
$\mathrm{Z}$ tekstu wynika ponadto, że powstały problem nie został jeszcze rozwiązany. W związku z tym sam osobiście włącza się do dyskusji, proponując własne rozwiązania przekazywane $\mathrm{w}$ formie pouczenia, a niejednokrotnie stanowczej zachęty.

Ponadto $\mathrm{z}$ treści listu można $\mathrm{z}$ wielką dozą pewności wywnioskować, co było przyczyną buntu. Wynika z niego, że niektórzy z prezbiterów zostali pozbawieni sprawowanej dotąd funkcji ${ }^{16}$. Klemens nie może pogodzić się z tym i oświadcza adresatom, że

„nie jest rzeczą słuszną odsuwać od tej posługi ludzi, którzy [...] za zgodą całego Kościoła służyli trzódce Chrystusowej w sposób nienaganny, z pokorą i spokojem. [...] I nie mały byłby to błąd pozbawiać godności biskupiej tych, co składają Bogu ofiary w nieskazitelnej pobożności”'17.

Ta wypowiedź nie wskazuje na negatywne zachowania prezbiterów, które w mniemaniu niektórych byłyby powodem usunięcia ich ze służby. Wręcz przeciwnie, Klemens podkreśla zalety owych mężów, ponieważ służą „,W sposób nienaganny, z pokorą i spokojem” oraz „W nieskazitelnej pobożności”. Skoro więc z jednej strony Klemens zauważa oddanie, nienaganność, pokorę i spokój prezbiterów, to dlaczego pojawiły się ogniska buntu i niezadowolenia? Najprawdopodobniej tę kwestię należy łączyć z etapem przechodzenia $\mathrm{z}$ apostolatu wędrownego do episkopatu lokalnego. Innymi słowy, nastąpił moment dostrzegania wyższości biskupa (vel prezbitera) w pełnieniu swych funkcji nad większą wspólnotą, np. miejską, nad przewodniczeniem małej grupie $\mathrm{w}$ ramach kościołów domowych. Stąd pojawiła się tendencja, by niektórych prezbiterów pozbawić sprawowania funkcji przewodniczenia ${ }^{18}$.

Czytelnik dowiaduje się także o dokonanych już wcześniej przypadkach pozbawiania tych kościelnych funkcji, kiedy autor listu oświadcza: „Widzimy bowiem, że niejednego odsunęliście od służby Bożej”'19. W kontekście tego zjawiska, które pojawiło się w korynckiej wspólnocie, biskup Rzymu ośmiela się wskazać na powód popychający niektórych do przyjęcia tak negatywnej postawy wobec prezbiterów. W tym celu przytacza podobne, a może nawet

${ }^{16}$ To zagadnienie omawia R.R. Noll, The Search for a Christian Ministerial Priesthood in 1 Clement, StPatr 13 (1975) 250-254.

${ }^{17}$ Clemens Romanus, Epistula ad Corinthios XLIV 3-4, SCh 167, 172, BOK 10, 71.

${ }^{18}$ Por. Prinzivalli - Simonetti, Introduzione. La lettera di Clemente ai Corinzi, s. 94-95.

${ }^{19}$ Clemens Romanus, Epistula ad Corinthios XLIV 6, SCh 167, 174, BOK 10, 71. 
identyczne, postępowanie z czasów Starego Testamentu, którego doświadczył Mojżesz. Było to wówczas, „kiedy godność kapłańska stała się przedmiotem zazdrości i pokolenia [Izraela] zaczęły się kłócić, któremu z nich ten zaszczyt się należy"20. Być może przypomnienie tego biblijnego wydarzenia odniosło pożądany skutek, a owocem m.in. takiego podejścia Klemensa wobec zachowania Koryntian była rezygnacja owych zuchwalców z ambicjonalnych zamiarów.

Wyartykułowanie moralnej oceny powyższego postępowania sprowadza się do dostrzeżenia dwóch aspektów. $Z$ jednej strony pojawia się tutaj oczywista wada, którą jest zatwardziałość serca - tak bardzo zwalczana przez Klemensa w jego liście ${ }^{21}$. Według niego, ta skaza na duszy człowieka jest podstawą zazdrości, o której pisze, czyli nieuporządkowanych uczuć wobec piastowania przez innych zaszczytnych funkcji. Natomiast $\mathrm{z}$ drugiej strony, należałoby, z pewną dozą ironii, pochwalić tego, kto pragnie dostąpić funkcji kapłańskiej i stać się pasterzem trzody Chrystusa. W ocenie Klemensa ta druga opcja jest jednak nieprawdziwa, ponieważ dokonuje się nieuczciwie, przy wykorzystaniu przemocy i wbrew woli wszystkich członków wspólnoty. Jeśliby nawet ktoś w jakiś sposób dostąpił tej godności, to - według Klemensa - nie dokonuje się to drogą lojalnego wyznaczania następców. Ten dyscyplinarny problem stał się dla biskupa Rzymu okazją do zabrania głosu w tej sprawie i wypowiedzenia swej opinii, która stała się ważnym argumentem dla późniejszych pokoleń.

3. Istota sukcesji apostolskiej. Klemens Rzymski nie posługiwał się w swoim liście terminem „sukcesja”, a więc nie był prekursorem zastosowania tego słowa. Po raz pierwszy użyto go w antygnostyckich polemikach w II w. w takim znaczeniu, by pseudoapostolskiej tradycji gnozy przeciwstawić prawdziwą tradycję apostolską 22.

Biskup Rzymu, pragnąc rozwiązać zaistniały problem we wspólnocie kościelnej Koryntu, w formie wykładu wyjaśnia członkom tej wspólnoty istotę misji apostolskiej. Ukazuje źródło jej pochodzenia i wyjaśnia ją następująco:

„Apostołowie głosili nam Ewangelię, którą otrzymali od Jezusa Chrystusa, a Jezus Chrystus został posłany przez Ojca. Chrystus przychodzi zatem od Boga, Apostołowie zaś od Chrystusa. Jedno i drugie, w tym właśnie porządku, stało się zatem z woli Bożej”23.

${ }^{20}$ Tamże XLIII 2, SCh 167, 170, BOK 10, 70.

${ }^{21}$ Więcej o tej postawie zob. N. Widok, Путь стремления к святости в изложении Климента Римского, w: St Clement's Papers. Materials of the Sixth International Conference „Church Archeology: Chersonesos - the city of St Clement”, ed. T.J. Jaszajewa, Sevastopol 2013, 84-89.

${ }^{22}$ Por. K. Rahner - J. Ratzinger, Episkopat und Primat, Freiburg im Breisgau 1961, 45; H. von Campenhausen, Kirchliches Amt und geistliche Vollmacht in den ersten drei Jahrhunderten, Tübingen 1953, 163-194.

${ }^{23}$ Clemens Romanus, Epistula ad Corinthios XLII 1-2, SCh 167, 168: „Oi ỏ đó 
Autor tego pouczenia wykazuje, że nowa rzeczywistość we wspólnocie kościelnej, o nazwie „sukcesja”, osadzona była w zamyśle i działaniu Boga,

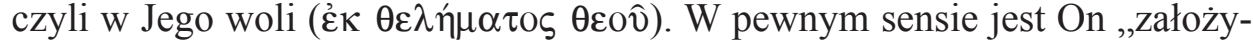
cielem" tego aktu, który potem dokonywał się w ludzkim działaniu. Klemens dowodzi, że Bóg stał się inicjatorem przekazywania zbawczych czynności. Uczynił to za pośrednictwem Jezusa Chrystusa, który został przez Niego po-

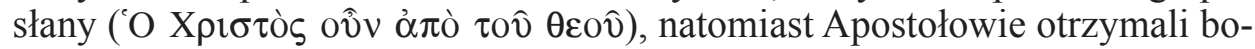
skie posłannictwo w postaci ewangelii od Jezusa Chrystusa (Oi ’̉

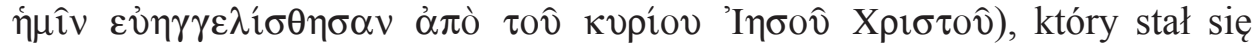
ostatecznie twórcą zasady przekazywania posłannictwa zbawczego. Obydwa akty, ściślej mówiąc - czynności przekazywania posłannictwa, dokonały się

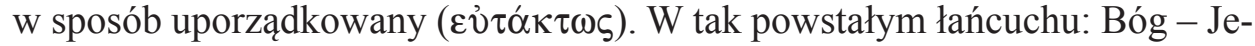
zus Chrystus - Apostołowie, dostrzegalna jest symbioza elementu boskiego i ludzkiego, polegająca na uzależnieniu działania Bożego od działania ludzkiego $^{24}$. W innym miejscu listu Klemens jeszcze raz wskazuje na Boże pochodzenie tego ważnego aktu, gdy wymienia Apostołów, „którym w Chrystusie Bóg zlecił tak wielkie dzieło" 25 . Również w tym stwierdzeniu ujęta została kolejność ogniw przekazu: od Boga przez Jezusa Chrystusa do Apostołów.

Po tym wstępnym założeniu, ukazującym źródło pochodzenia sukcesji, Klemens przechodzi do przedstawienia działalności Apostołów. Opis tych czynności został przez niego jasno wyakcentowany:

„[...] wyruszyli Apostołowie w świat i z tą pewnością, jaką daje Duch

Święty, głosili dobrą nowinę o nadchodzącym Królestwie Bożym. Nauczając po różnych krajach i miastach spośród pierwocin [swojej pracy] wybierali ludzi wypróbowanych duchem i ustanawiali ich biskupami i diakonami dla przyszłych wierzących"26.

Treść tego tekstu odnosi się już tylko do Apostołów. Biskup Rzymu przedstawia adresatom istotę ich działalności, a więc tych wybranych i posłanych przez Jezusa Chrystusa. Po różnych krajach i miastach z pomocą Ducha Świętego głosili dobrą nowinę, tj. ewangelię, o Królestwie Bożym. Jak Chrystus powierzył apostołom zadanie głoszenia Jego nauki, tak oni zdecydowali o wyborze swoich następców, przekazując im tę samą misję do wykonania. W ten sposób ustanawiali kontynuatorów przekazywania posłannictwa zbawczego,

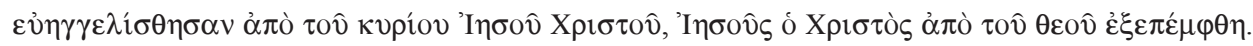

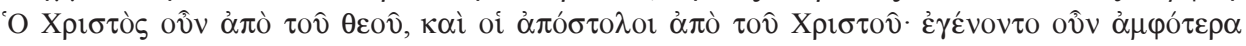

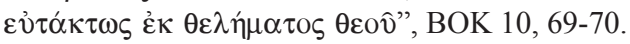

${ }^{24}$ Por. S. Nagy, Chrystus w Kościele. Zarys eklezjologii fundamentalnej, Wrocław 1982, 196.

${ }^{25}$ Clemens Romanus, Epistula ad Corinthios XLIII 1, SCh 167, 170: „oi દ̉v Xpı

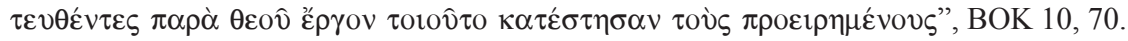

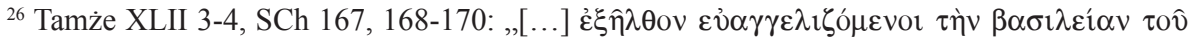

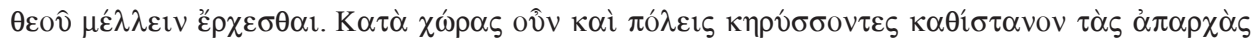

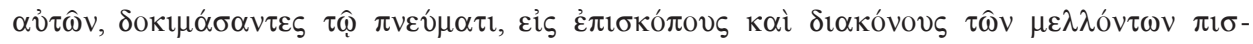

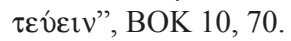


tworząc zasadę bezpośredniego oddawania w kolejne ręce funkcji związanych z ówczesnymi czynnościami liturgicznymi i pasterskimi ${ }^{27}$. To oczywiste dla Apostołów przedsięwzięcie, wynikające z bieżących zapotrzebowań na głosicieli nauki Chrystusa oraz z faktu nieuchronnego ich odejścia, zwane jest właśnie sukcesją.

Przytoczony tekst zwraca ponadto uwagę na dwie kwestie wiążące się z zasadą sukcesji. Pierwsza odnosi się do kwalifikacji następców. Jak relacjonuje Klemens, Apostołowie „wybierali ludzi wypróbowanych duchem”

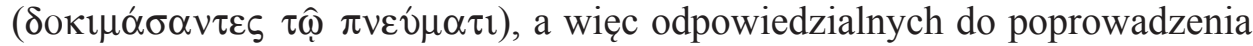
dalej tej misji, jaką otrzymali. Najpierw musieli wykazać się zaangażowaniem w sprawach dotyczących ewangelizacji, a także odpowiednim poziomem obyczajowości moralnej, aby potem można im było powierzyć apostolskie funkcje. Druga kwestia dotyczy kategorii wspomnianych następców, lub też dokładniej stopni. Klemens wymienia bowiem dwa stopnie, którymi są biskupi

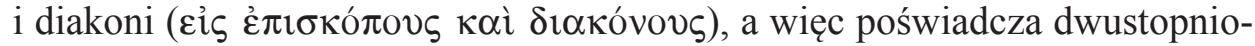
wą hierarchię w Kościele pod koniec I w. w Rzymie. Kilkakrotnie w swoim liście wymienia biskupów i diakonów - zawsze obok siebie, nigdy oddzielnie. Autor listu posługuje się też pojęciem ,„prezbiterzy”, które stosuje w odniesieniu do biskupów lub biskupów i prezbiterów uznawanych za przełożonych ${ }^{28}$.

W liście Klemensa do Koryntian znajduje się ponadto wypowiedź, która wylicza kolejne ogniwo sukcesji apostolskiej. Poprzedzona jest nawiązaniem do incydentu z czasów Mojżesza, a więc do zazdrości o godność kapłańską. Adresaci w Koryncie odczytali bowiem następujący tekst w otrzymanym liście:

„Także i nasi Apostołowie wiedzieli przez Pana naszego Jezusa Chrystusa, że będą spory o godność biskupią. $Z$ tego też powodu, w pełni świadomi, co przyniesie przyszłość, wyznaczyli biskupów i diakonów, a później dodali jeszcze zasadę, że kiedy oni umrą, inni wypróbowani mężowie mają przejąć ich posługe?" 29 .

Autor listu jeszcze raz powtórzył zasadę, o której wcześniej pouczył, a mianowicie tę, że Apostołowie wyznaczyli biskupów i diakonów na swoich następców. W przytoczonej wypowiedzi Klemens myślą wybiega do następnego pokolenia, objaśniając kolejną zasadę wprowadzoną przez Apostołów. Polega ona na tym, że ci wybrani przez Apostołów biskupi i diakoni dopiero po swojej śmierci przekażą innym swą posługę. Także w odniesieniu do nich Klemens kładzie nacisk na kwalifikacje moralne, pisząc, że to będą ,inni wy-

${ }^{27}$ Por. E. Bammel, Die Anfänge des Sukzessionsprinzips im Urchristentum, w: La tradizione: forme e modi, SEA 31, Roma 1990, 63-72.

${ }^{28}$ Por. H. Seweryniak, Świadectwo i sens. Teologia fundamentalna, Płock 2001, 432.

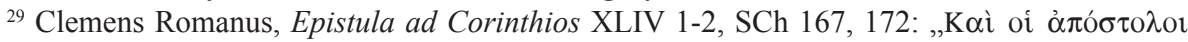

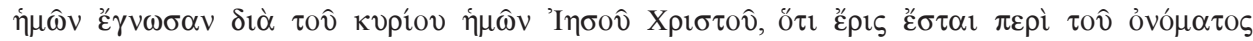

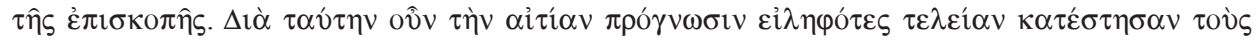

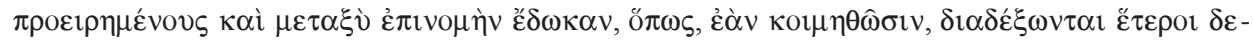

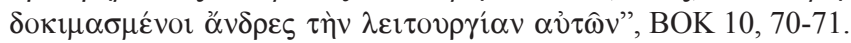


próbowani mężowie". W ten sposób nastąpiło wydłużenie o kolejne ogniwo łańcucha, zwanego sukcesją apostolską.

W powyższym fragmencie listu biskup Rzymu wyraźnie podkreśla jeszcze bardzo ważny szczegół: przejmowanie posługi może dokonywać się dopiero po śmierci poprzedników. Zatem nie wolno za życia odsuwać ich od sprawowanych funkcji i brutalnie pozbawiać zajmowanego stanowiska, ponieważ są oni „wyznaczeni przez Apostołów lub też później przez innych wybitnych mężów"30. Oznacza to, że owi później żyjący „wybitni mężowie” mają tę samą władzę, co Apostołowie. Chrystus nie musiał więc tworzyć innego aktu w przekazywaniu misji apostolskiej dla następców Apostołów. Zarówno bowiem Apostołowie, jak i ich następcy, tworzą ontologicznie jedną całość, w której istnieje jedna nieprzerwana ciągłość tego samego posłannictwa $^{31}$. Zaproponowana Koryntianom przez Klemensa zasada przekazywania posłannictwa apostolskiego, zwana sukcesją, jak wiadomo, nie znalazła żadnych zastrzeżeń u adresatów. Nie są znane żadne negatywne odpowiedzi słane do Rzymu z Koryntu, bądź też potem z innych miejscowości. Wręcz przeciwnie, to rozwiązanie zostało przyjęte z aprobatą, o czym świadczą późniejsze świadectwa ${ }^{32}$.

Z całym prawdopodobieństwem można zakładać, że przekazana wspólnocie kościelnej propozycja rozwiązania kwestii dyscyplinarnej na drodze sukcesji była znana Klemensowi z obserwacji lokalnej wspólnoty w Rzymie lub też przekazana mu przez innych ewangelizatorów na zasadzie podzielenia się swoimi doświadczeniami. Wśród tych ostatnich należy wskazać na św. Pawła, który przebywał w Rzymie w latach $61-67^{33}$. Jednak dla Klemensa jako biskupa Rzymu, w pewnym sensie też będącego spadkobiercą działalności misjonarskiej św. Pawła, były znane treści, jakie zawierały jego listy, a także Dzieje Apostolskie, przedstawiające wiele opisów dotyczących początków organizowania się wspólnot kościelnych. $\mathrm{Z}$ ich treści wynika, że wypracowano swego rodzaju zasadę przekazywania posłannictwa zbawczego w Kościele, które stawało się coraz bardziej znane w praktyce poszczególnych wspólnot. Stanisław Nagy, porównując działalność św. Pawła z przekazem Klemensa Rzymskiego, stwierdza, że

„istnieje między nimi zbieżność przede wszystkim co do faktu istnienia ustalonej przez apostołów zasady przekazywania posłannictwa apostolskiego. To,

${ }^{30}$ Tamże XLIV 3, SCh 167, 172, BOK 10, 71.

${ }^{31}$ Por. Nagy, Chrystus w Kościele, s. 204-205.

32 Por. R. Trevijano, Successione, DPAC III 3328-3331. Autor wymienia pisarzy wczesnochrześcijańskich, którzy nawiązują do apostolskiej sukcesji i rozwijają jej zasadność. Jest wśród nich Hegezyp, Ireneusz z Lyonu, Cyprian, Klemens Aleksandryjski i przede wszystkim Euzebiusz z Cezarei.

${ }^{33}$ Por. E. Dąbrowski, Dzieje Pawła z Tarsu, Warszawa 1953, 487 i 572. 
co św. Klemens ukazuje bowiem jako prawo sformułowane przez apostołów, św. Paweł stosuje w praktyce życia kościelnego"34.

Podróże misyjne św. Pawła wraz z praktyką prowadzenia apostolatu wędrownego, a potem kilka lat spędzonych w Rzymie, gdzie zostało zredagowane kilka jego listów, pozostawiły zatem trwały ślad w świadomości kościelnej chrześcijan późniejszych pokoleń.

\section{$* * *$}

Podsumowując dokonane wyżej analizy fragmentów Listu do Koryntian Klemensa Rzymskiego, należy stwierdzić, że tekst tego listu okazał się świadectwem ukazującym problemy, z jakimi zmagała się wspólnota w Koryncie. Wśród nich sprawą powodującą rozbieżności i spory w tej wspólnocie było odebranie niektórym prezbiterom sprawowanej funkcji, zwłaszcza w odniesieniu do przewodniczenia małym grupom w ramach kościołów domowych. Klemens próbuje rozstrzygnąc ten spór, nawołując poszkodowanych prezbiterów do pokory i rezygnacji z nieuporządkowanych postaw wobec piastowania tych funkcji, a także do poddania się rygorowi lojalnego wyznaczania następców. Przeprowadzona przez Klemensa argumentacja, oparta na biblijnych przesłankach, stała się kluczem do późniejszego stałego sposobu przekazywania posłannictwa zbawczego. Zasada tego przekazywania została nazwana „sukcesją apostolską”, a wypracowane przez Klemensa elementy tej argumentacji stały się ważnym osiągnięciem wczesnego Kościoła i trwałym wkładem w tworzącą się eklezjologię.

\section{SAINT CLEMENT OF ROME ON APOSTOLIC SUCCESSION}

\section{(Summary)}

1910. anniversary of the death of Saint Clement of Rome, the third successor of Bishop of Rome, celebrated a few years ago $(\dagger 101)$, became an opportunity to remind his teaching, which he left in the Epistle to the Corinthians, written by him. The content of this letter is an important witness of the emerging church organization. That, what was happening in Corinth and, without a doubt, in Rome, is one of the stages of the Church's history of major importance. The contemporary situation related to the authority prompted the acceptance of the institutional proposal based on the Holy Scripture and the practice of the Apostles. Transferring saving mission "from hands to hands", called apostolic succession, proved to be an extremely important achievement of the early Church to preserve its credibility in the following centuries.

\footnotetext{
${ }^{34}$ Nagy, Chrystus w Kościele, s. 201.
} 
Saint Clement of Rome is one of the first witnesses of such message and he is also the author of this essential ecclesiological element. The letter that was sent to the inhabitants of Corinth contains the earliest foundations which, after years, become an essential criterion of Catholicism. The original foundations of theological thinking can be already seen in the teaching of Saint Clement. Many later theologians referred to this doctrine, adding further ecclesiological consequences emerging from it.

Key words: Clement of Rome, ecclesiastical authority, Apostolic succession, Church organization, Corinth.

Słowa kluczowe: Klemens Rzymski, kościelne przełożeństwo, sukcesja apostolska, organizacja kościelna, Korynt. 